\title{
POLIGAMI PERSPEKTIF KITAB AL-TAFSĪR AL-WASĪT LI AL-QUR'ĀN AL-KARĪM
}

\author{
Ali Hendri \\ UIN Sunan Kalijaga Yogyakarta \\ Jalan Laksda Adisucipto, Caturtunggal, Depok, Papringan, \\ Caturtunggal, Kec. Depok, Kabupaten Sleman, Daerah Istimewa Yogyakarta 55281 \\ Email : Hendrymukhtar@yahoo.com
}

\begin{abstract}
This article discusses polygamy in the perspective of al-Tafsīr al-Wasīt Li al-Qur'ān al-Karīm writen by Muhammad Sayyid Tāntāwī. This research employs descriptive analysis method and gender theory. In this study, the authors found that the book al-Tafsīr al-Wasīt li al-Qur'ān al-Karīm explains about polygamy from various aspects. In terms of sababunnuzul, this book only describes the general history of the decline of polygamy verse. But in historical terms, this tafsir describes the practice of polygamy that occurs in several nations. According to this tafsir the law of polygamy is allowed only on condition of being able to do justice. However, in certain circumstances (emergency) polygamy becomes even mandatory to do. According to him, the permissibility of this polygamy is merely a dispensation to avoid adultery. In certain parts of this commentary, the author discovers the existence of gender justice, but on the other point, the tafsir is seemingly gender biased instead.
\end{abstract}

Keywords:

al-Tafsīr al-Wasīt Li al-Qur’ān al-Karīm; Muhammad Sayyid Tāntāwī ; Polygamy.

\begin{abstract}
Abstrak
Artikel ini membahas tentang poligami menurut sudut pandang kitab al-Tafsìr al-Wasìt Li alQur'ān al-Karīm karya Muhammad Sayyid Tāntāwī dengan menggunakan metode analisa deskriptif dan teori gender. Dalam penelitian ini, penulis menemukan bahwa kitab al-Tafsīr alWasìt Li al-Qur'ān al-Karìm ini membahas poligami dari berbagai aspek. Dari segi sababun nuzul, kitab ini hanya menggambarkan secara umum sejarah turunnya ayat poligami. Sementara dari segi historisnya, kitab ini menjelaskan tentang praktik poligami yang terjadi pada beberapa bangsa. Menurut kitab ini hukum poligami adalah boleh dengan syarat mampu berlaku adil. Namun, dalam keadaan tertentu (darurat) poligami bahkan menjadi wajib untuk dilakukan. Menurutnya, kebolehan poligami ini hanyalah merupakan despensasi untuk menghindari zina. Di bagian tertentu dari tafsir ini, penulis menemukan adanya keadilan gender, akan tetapi di sisi lain, kitab ini tidak terlepas dari bias gender.
\end{abstract}

Keywords :

al-Tafsīr al-Wasīt Li al-Qur’ān al-Karīm; Muhammad Sayyid Tāntāwī ; Poligami.

\section{A. PENDAHULUAN}

Salah satu masalah yang selalu hangat diperbincangkan di kalangan ahli hukum dan mufassir adalah masalah poligami. Poligami sebagai salah satu bentuk perkawinan bagaikan dua sisi mata uang yang tidak dapat terpisahkan, selalu ada pihak yang menolak dan mendukungnya. Kata poligami sendiri selalu identik dengan kontroversi baik dalam hukum Islam maupun dalam realitas sosial. Mereka yang anti poligami melontarkan berbagai tuduhan yang mendiskreditkan dan mengidentikkan poligami dengan hal-hal yang negatif. Sedangkan bagi kalangan yang pro, mereka melegalkan poligami dan meyakini bahwa poligami telah dipraktikkan berabadabad lamanya oleh berbagai bangsa di dunia.

Bahkan di kalangan ulama sendiri terjadi perbedaan pendapat, yaitu antara ulama tradisional dengan ulama kontemporer. Ulama tradisional membolehkan poligami sementara ulama kontemporer terutama kalangan feminis mempermasalahkan dan memperberat syaratsyarat yang harus dipenuhi oleh laki-laki yang ingin poligami. Bagi kalangan femenis, poligami dianggap sebagai salah satu bentuk ketidaksetaraan antara laki-laki dan perempuan. Selain itu, poligami juga dianggap sebagai peninggalan masa jahiliyah, di mana pada waktu itu perempuan diperlakukan 
sebagai makhluk second class yang keberadaannya tidak diperhitungkan sehingga mereka bebas memiliki istri berapa saja.

Oleh karena permasalahan poligami ini berkaitan erat dengan relasi antara laki-laki dan perempuan, menurut penulis akan lebih tepat jika masalah poligami ini dilihat dari perspektif gender sebagai pisau bedahnya. Agar masalah poligami tidak selalu dipahami secara parsial sehingga dapat dipraktikkan secara semena-mena. Sebab, praktik poligami yang terjadi di lapangan sama sekali berbeda dari tujuan dibolehkannya poligami oleh alQur'an. Kebanyakan praktik poligami yang terjadi hanya karena alasan hasrat (syahwat) semata, bukan lagi karena ingin melindungi dan mengayomi.

\section{B. PEMBAHASAN}

\section{Gender}

Gender $^{1}$ merupakan realitas sosial yang dibentuk oleh struktur keyakinan, sosial, ekonomi, dan politik tertentu. ${ }^{2}$ Konstruksi gender selama ini menempatkan laki-laki sebagai pihak yang superior, dan perempuan sebagai pihak yang inferior, menjadi objek dan korban eksploitasi. Statusnya tidak lebih sebagai istri dan ibu yang perannya hanya dalam ranah domestik. ${ }^{3}$

\footnotetext{
${ }^{1}$ Istilah "gender" pertama kali diperkenalkan oleh Robert Stoller (1968) untuk memisahkan pencirian manusia yang didasarkan pada pendefinisan yang bersifat sosial budaya dengan pendefinisan yang berasal dari ciri-ciri fisik biologis. selain itu, Ann Oakley (1972), adalah orang yang sangat berjasa dalam mengembangkan istilah dan pengertian gender dalam ilmu sosial. Menurutnya seks (jenis kelamin) adalah kodrat Tuhan yang permanen, yang membedakan antara laki-laki dan perempuan. Sedangkan gender adalah perbedaan antara laki-laki dan perempuan berdasarkan behavioral differences, (Riant Nugroho, Gender dan Strategi Pengarus-Utamaannya di Indonesia, (Yogyakata: Pustaka Pelajar, 2011), 3-5.). Lihat juga Sri Purwaningsih, Kiai \& Keadilan Jender, (Semarang: Walisongo Pers, 2009), 2.

${ }^{2}$ Siti Ruhaini Dzuhayatin, Rezim Gender Muhammadiyah: Kontestasi Gender, Identitas, dan Eksistensi, (Yogyakarta: Suka Press UIN \& Pustaka Pelajar, 2015), 7-8.

3Jamal Ma'mur, Rezim Gender di NU, (Yogyakarta: Pustaka Pelajar, 2015), 41.
}

Perbedaan gender (gender differences) antara laki-laki dan perempuan berlangsung terus menerus dalam sejarah yang sangat panjang dan kompleks hingga sekarang. Ia dibentuk, disosialisasikan, diperkuat bahkan dikonstruksikan secara sosial hingga banyak yang dianggap sebagai ketentuan Tuhan (seolah-olah bersifat biologis yang tidak dapat diubah lagi), sehingga perbedaan gender dianggap dan dipahami sebagai sebuah kodrat. ${ }^{4}$ Para pejuang gender ${ }^{5}$ berusaha semaksimal mungkin untuk meminimalisir kesenjangan menuju kondisi yang kondusif bagi kesetaraan laki-laki dan perempuan, yaitu pembebasan perempuan dari ketertindasan, termasuk ideologis, agama, budaya, struktur politik dan lain-lain. ${ }^{6}$

Dalam perspektif Islam sekalipun, kesetaraan jender mendapat perhatian khusus. Ini dapat ditemukan dalam ajaran Islam itu sendiri yang memberi dorongan kepada pihak perempuan untuk lebih maju, dan tampil sebagai pemimpin bukan saja di rumah tetapi di semua ranah publik sebagaimana Ratu Balqis yang berhasil memimpin negara superpower.

Sebagai sebuah konstruksi, gender memiliki beberapa karakteristik yang membedakannya dari jenis kelamin biologis yang bersifat kodrati. Sifat atau karakteristik pertama, gender dapat berubah-ubah atau tidak permanen. Banyak fakta sejarah yang

\footnotetext{
${ }^{4}$ Muhammad Zamroni, "Perempuan dalam Kajian Komunikasi Politik dan Gender", dalam jurnal Dakwah, Vol. XIV, No. 1, Jan-Des 2013, 107.

${ }^{5}$ Gerakan gender melahirkan pejuang-pejuang gender yang lebih populer dengan sebutan aktivis feminis. Konstruksi pemikiran kaum feminis ini adalah memberikan wahana kepada kaum perempuan untuk bekerja, berkiprah di luar keluarga sebagai anggota masyarakat. Tujuan utamanya adalah melakukan identifikasi sejahmana terdapat kesesuaian antara pandangan feminis dan pandangan keagamaan terhadap kedirian dan bagaimana menjalin hubungan yang paling menguntungkan satu dengan lainnya, (Jamal Ma'mur, Rezim Gender di NU..., 43).

${ }^{6}$ Jamal Ma'mur, Rezim Gender di NU..., 42.

${ }^{7}$ Salmah Intan, "Kedudukan Perempuan dalam Domestik dan Publik Perspektif Gender" dalam jurnal Politik Profetik, Vol. 3, No. 1, 2014.
} 
menunjukkan bahwa berbagai konstruksi masyarakat tentang stereotipi perempuan tidak lagi kontekstual dan tidak relevan dengan realitas kehidupan. Karakteristik kedua, sifatnya yang lentur dan cair, dapat dimiliki, diletakkan atau diperankan baik oleh laki-laki maupun perempuan. Karakteristik ketiga, gender dapat berbeda tergantung pada dan ditentukan oleh perbedaan waktu, tempat, kondisi dan aspek-aspek lainnya. Karakteristik lain dari gender yang menonjol adalah sifatnya yang vernacular atau bersifat kedaerahan. ${ }^{8}$

Menurut teori gender ini, terdapat ragam ketidakadilan terhadap jenis kelamin tertentu yang disebabkan oleh perbedaan gender, di antaranya adalah ${ }^{9}$ :

Marginalisasi, yaitu proses peminggiran yang merugikan salah satu pihak.

Subordinasi, yaitu sifat yang menempatkan perempuan pada posisi tidak penting atau adanya pihak yang superior dan inferior.

Stereotype, yaitu pelabelan atau penandaan negatif terhadap kelompok atau jenis kelamin tertentu.

Violence, yaitu merupakan kekerasan atau serangan terhadap fisik maupun integritas mental psikologis seseorang yang dilakukan terhadap jenis kelamin tertentu. dan

Beban kerja/ganda, yaitu pekerjaanpekerjaan yang bersifat domestik (mengurus rumah dan mengasuh anak).

Sekilas Tentang Kitab al-Tafsīr al-Wasīt Li al-Qur'ān al-Karīm

Kitab al-Tafsìr al-Wasìt Li al-Qur'ān alKarīm ini adalah salah satu karya Muhammad Sayyid Tāntāwī yang seluruhnya berjumlah 15 jilid. Penulisan kitab tafsir ini dimulai sejak tahun 1965 dan selesai pada tahun 1975, kemudian pada tahun itu juga tafsir ini untuk pertama kalinya diterbitkan. Kitab al-Tafsīr alWasìt Li al-Qur'ān al-Karìm adalah kitab tafsir kontemporer yang menafsirkan alQur'an seluruhnya yaitu $30 \mathrm{juz}$, mulai dari

\footnotetext{
${ }^{8}$ Inayah Rohmaniyah, Konstruksi Patriarki dalam Tafsir Agama: Sebuah Jalan Panjang, (Yogyakarta: Diandra Pustaka Indonesia, 2014), 11-13.

${ }^{9}$ Riant Nugroho, Gender dan Strategi PengarusUtamaannya di Indonesia, 9.
}

surah al-Fātihah sampai surah an-Nās. Seluruhnya memuat 6924 halaman dalam versi penerbit $D \bar{a} r$ as-Sa'ādah.

Muhammad Sayyid Tāntāwī menulis Tafsir ini secara sistematis, sehingga menjadikan kitab al-Tafsīr al-Wasìt Li al-Qur'ān al-Karīm ini terkesan sederhana, namun sarat dengan makna. Seperti dalam menafsirkan ayat demi ayat, ia menyesuaikan sesuai dengan urutan Mushaf Utsmani, yaitu yang dikenal dengan metode tahlili. Artinya mufassir menjelaskan aspek-aspek yang terdapat pada ayat-ayat yang telah ditafsirkan dan selanjutnya menerangkan makna-maknanya sesuai dengan keahlian mufassir. ${ }^{10}$

Kalau dilihat dari bentuknya, secara umum bentuk penafsiran terbagai menjadi tiga, yaitu tafsir bi al-ma'tsū $r^{11}$, tafsir bi ar-ra'yi ${ }^{12}$ dan tafsir bi al-isyāri. ${ }^{13}$ Sedangkan bentuk penafsiran yang digunakan oleh Muhammad Sayyid Tāntāwī dalam tafsirnya adalah menggunakan metode penggabungan antara tehnik penafsiran bi al-ma'tsür dan bi al-ra'yi. Artinya, Muhammad Sayyid Tāntāwī dalam menafsirkan ayat tidak lantas melepaskan semua yang terkait dengan ayat karena Muhammad Sayyid Tantawi sangat memperhatikan betul terhadap bagaimana asbāb an-nuzūl suatu ayat.

\footnotetext{
${ }^{10}$ Nuril Habibi, "Persamaan Hak Antara Laki-laki dan Perempuan..., 7.

${ }^{11}$ Adalah tafsir yang merujuk kepada riwayat atau tafsir yang menjadikan riwayat sebagai sumber utamanya (Nashruddin Baidan, Wawasan Baru Ilmu Tafsir, cet. ke-2 (Yogyakarta: Pustaka Pelajar, 2011), 370).

${ }^{12}$ Istilah al-ra'yi berarti pikiran atau nalar, karena itu tafsir bi al-ra'yi dipahami sebagai penafsiran al-Quran yang menjadikan hasil penalaran atau pikiran sebagai sumber utamanya. (Junizar Suratman, "Pendekatan Penafsiran al-Qur'an yang Didasarkan pada Instrumen Riwayat, Nalar, dan Isyarat Batin”, Intizar, Vol. 20, No. 1, 2014, 50-51.

${ }^{13}$ Muhammad Husain az-Zahabi mendefinisikan isyarah sebagai sebuah usaha untuk menjelaskan kandungan al-Quran dengan melakukan pentakwilan ayat-ayat sesuai dengan isyarat yang tersirat, namun tidak mengingkari yang tersurat atau dimensi zahir ayat. (Junizar Suratman, 'Pendekatan Penafsiran al-Qur'an yang Didasarkan pada Instrumen Riwayat, Nalar, dan Isyarat Batin”, Intizar, Vol. 20, No. 1, 2014, 50-51).
} 
Selain itu, Muhammad Sayyid Tāntāwī juga menjelaskan lafaz-lafaz al-Qur'an dari perspektif bahasa (lughoh), setelah itu beliau menjelaskan maksud dari lafadz-lafadz itu apabila diperlukan. Selanjutnya, beliau menjelaskan makna ijmāli ayat dari segi balāgah, bayān, adab, dan ahkām. Maknamakna ini kadang-kadang juga dikaitkan dengan merujuk kepada ayat-ayat lain, alAhādis al-Nubuwwah, dan perkataanperkataan dari al-salaf al-Salih. ${ }^{14}$

Di samping itu, ia juga menyebutkan sumber-sumber terdahulu seperti al-Tābari, Ibnu Katsīr, al-Alūsī, al-Qāsimī, alZamakhsyarī, Abī Hayyān karyanya al-Manār, Fakhrurrāā dan penafsir-penafsir lainnya. Dan apabila di dalam sebuah penafsiran ia menemukan banyak pendapat-pendapat, ia hanya menfokuskan pada pendapat-pendapat yang ia anggap lebih benar, hal ini dimaksudkan agar tidak bertele-tele dalam menafsirkan al-Qur'an sehingga terjebak dalam perdebatan yang ia anggap tidak perlu. $^{15}$

Metode penafsiran yang biasa digunakan oleh para mufassir, di antaranya ada yang bersifat meluas/melebar dan secara global, tetapi ada juga yang menafsirkannya dengan cara melakukan studi perbandingan, dan sistematis. Berdasarkan berbagai metode tersebut, sebagian ahli tafsir seperti Abd alHayy al-Farmawi, menyebutkan empat macam metode, yaitu tahlili ${ }^{16}$, ijmali $^{17}$, muqarin ${ }^{18}$ dan maudhu'i. ${ }^{19}$

\footnotetext{
${ }^{14}$ Sayyid Muḥammad 'Al̄̄ Iyāz̄̄, al-Mufassirūn Hayātuhum wa Manhājuhum, Vol.3,(Teheran: Wizārat Śaqāfah wa al-Irsyād al-Islāmi, 1386 H), 1301.

${ }^{15}$ Sayyid Muḥammad 'Alī Iyāzī, al-Mufassirīn Hayātuhum wa Manhājuhum, Jilid. III. 1301.

${ }^{16}$ Metode penafsiran ayat-ayat al-Qur'an yang dilakukan dengan cara mendeskripsikan uraian-uraian makna yang terkandung dalam ayat-ayat al-Qur'an dengan mengikuti tertib surat. (Muhammad Amin Suma, Ulumul Qur'an (Jakarta: PT RajaGrafindo Persada, 2013), 379.

${ }^{17}$ Penafsiran al-Qur'an yang dilakukan dengan cara menguraikan isi kandungan al-Qur'an melalui pembahasan yang bersifat umum. (Muhammad Amin Suma, Ulumul Qur'an..., 381).
}

Adapun metodologi yang digunakan oleh Muhammad Sayyid Tantawi dalam menafsirkan al-Qur'an adalah metode tahlili/analisis, dengan menguraikan makna ayat al-Qur'an menggunakan bahasa yang ringkas, dan mudah dipahami terkait kandungan makna ayat-ayat al-Qur'an dengan mengikuti tertib urutan surat-surat dan ayatayat dalam al-Qur'an dengan melakukan analisis di dalamnya, baik itu dengan merujuk terhadap makna lafadz ayat dari ayat yang lain (tafsir ayat bi al-ayat) atau dari hadis dan pendapat para ulama salaf. ${ }^{20}$

Sedangkan corak penafsiran yang digunakan oleh Muhammad Sayyid Tantawi dalam kitab al-Tafsīr al-Wasìt Li al-Qur'ān al-Karim adalah menggunakan corak tafsir aladabi wa al-ijtima'i. ${ }^{21}$ Sebagaimana yang dikatakan oleh Muhammad Ridha bahwa corak tafsir al-adabi wa al-ijtima'i tidak terlalu menekankan pada aspek nahwu, bahasa, istilah-istilah dalam balaghah dan berbagai perbedaan mazhab, namun lebih kepada upaya pemahaman sosiologis Islam. Selain itu, juga disesuaikan dengan al-Qur'an atau nas dengan menggunakan gaya bahasa yang mudah dipahami, dan juga disesuaikan dengan peristiwa (sunnatullah) yang terjadi,

18 menafsirkan al-Qur'an dengan cara membandingkan ayat-ayat al-Qur'an yang memiliki redaksi yang berbeda padahal isi kandungannya sama. (Muhammad Amin Suma, Ulumul Qur'an..., 383).

${ }^{19}$ Metode penafsiran yang penguraiannya fokus pada satu tema tertentu. (Muhammad Amin Suma, Ulumul Qur'an..., 391).

20 Sayyid Muḥammad Alī Iyāzī, al-Mufassirūn Hayātuhum wa Må̄hājuhum..., 1300.

${ }_{21}$ tafsir yang menitik beratkan pada ketelitian ungkapan-ungkapan redaksi al-Qur'an yang disusun dengan bahasa yang lugas dan indah dengan menonjolkan tujuan turunnya al-Qur'an, lalu mengaplikasikannya dalam kehidupan masyarakat dan sejalan dengan perkembangan masyarakatnya. Salah satu contoh tafsir yang bercorak al-adabi wa alijtima 'iadalah tafsir al-Manar karya Muhammad Abduh dan Rāsyid Ridhā. (Ahmad Izzan, Metodologi Ilmu Tafsir (Bandung: Tafakur, 2011), 199-200. Lihat juga Naqiyah Mukhtar, Ulumul Qur'an(Purwokerto: STAIN Press, 2013), 173). 
baik berupa kemasyarakatan atau tatanan peradaban. $^{22}$

\section{Poligami sebagai Sebuah Solusi}

Dari segi bahasa, poligami berasal dari bahasa Yunani, al-Tafsīr al-Wasīt Li al-Qur'ān al-Karīm; Muhammad Sayyid Tāntāwī ; Poligami. al-Tafsīr al-Wasīt Li al-Qur'ān alKarīm; Muhammad Sayyid Tāntāwī ; Poligami. al-Tafsīr al-Wasīt Li al-Qur'ān alKarīm; Muhammad Sayyid Tāntāwī ; Poligami. atau polus yang berarti banyak dan gamein atau gamos yang berarti kawin atau perkawinan. ${ }^{23}$ Poligami $^{24}$ diartikan sebagai perkawinan yang lebih dari satu, tetapi di dalam Islam disertai dengan sebuah batasan, yaitu diperbolehkan hanya sampai empat orang wanita karena ada indikasi nash. ${ }^{25}$ Poligami merupakan salah satu bentuk perkawinan di mana seorang suami dalam waktu yang bersamaan mempunyai lebih dari satu istri. ${ }^{26}$

${ }^{22}$ Mohammad Ridho, Islam, Tafsir dan Dinamika Sosial: Ikhtiar Memaknai Ajaran Islam (Yogyakarta: Teras, 2010), 70-71.

${ }^{23}$ Tihami, Sohari Sahrani, Fikih Munakahat-Kajian Fikih Nikah Lengkap (Jakarta: Rajawali Pers, 2013), hlm. 351. Lihat juga Aa Sofyan, "Analisis Pemkikiran Musdah Mulia Terhadap Keharaman Poligami”, Bil Dalil (Jurnal Hukum Islam Keluarga), Volume. 1, No. 2, Juli-Desember 2016, 3.

${ }^{24}$ Praktek poligami menjadi fenomena tersendiri yang seringkali dipersoalkan yang kemudian menimbulkan pro kontra dalam persepsi masyarakat. Kelompok yang pro memandang bahwa poligami tidak dilarang dalam agama karena dalilnya terdapat di dalam AlQur'an maupun as-Sunnah. Sementara kelompok yang kontra beranggapan bahwa poligami merupakan tindakan yang tidak adil terhadap relasi suami dan istri. Lihat juga Rohmat, "Poligami dalam al-Qur'an", Tribakti, Volume. 14, No. 2, Juli 2005, 2.

${ }^{25}$ Bangsa Arab memperbolehkan praktik poligami tanpa batasan maksimum, ini merupakan spirit sistem paternalistik yang dianut suku-suku nomaden Madji bin Manshur bin Sayyid asy-Syuri, Mahkota PengantinBingkisan Istimewa untuk Istri, "terj”. Ahmad Syaikhu (Jakarta: Pustaka at-Tazkia, 2017), 135.

${ }^{26}$ Syariat Islam memperbolehkan poligami dengan batasan sampai empat orang dan mewajibkan berlaku adil kepada mereka, baik dalam urusan pangan, pakaian, tempat tinggal, serta lainnya yang bersifat kebendaan tanpa membedakan antara istri yang kaya dan istri yang miskinEdi Darmawijaya, "Poligami dalam Hukum Islam dan Hukum Positif”, Gender
Pada dasarnya asas perkawinan dalam Islam adalah monogami. ${ }^{27}$ Hal ini dapat dipahami dari surah an-Nisa' (4): 3, di mana Allah memberi peluang untuk beristri sampai empat orang. Melihat peluang itu dibarengi oleh syarat yang sebenarnya cukup berat untuk ditunaikan kecuali oleh orang-orang tertentu saja. ${ }^{28}$ Namun demikian, al-Qur'an telah memberikan satu kata kunci yang mengikat praktik poligami yang sebelumnya menjadi tradisi masyarakat Arab yang patriarkal dan barbar, yaitu keadilan. Keadilan merupakan konsep dasar di dalam ajaran Islam. Keadilan menjadi ruang yang mempertemukan dan sekaligus mempersatukan antara eksistensi laki-laki dan perempuan, baik secara seksual, sosial maupun politik. ${ }^{29}$

Poligami sebagai salah satu bentuk perkawinan bagaikan dua sisi mata uang yang tidak dapat terpisahkan, selalu ada pihak yang menolak dan mendukungnya. Kata poligami identik dengan kontroversi baik dalam hukum Islam maupun dalam realitas sosial. ${ }^{30} \mathrm{Di}$ antaranya adalah Muhammad Sayyid Tantawi menjelaskan bahwa tidak dibolehkannya poligami bagi seorang laki-laki adalah jika ia tidak mampu adil, sehingga menjadi penghalang untuk memberikan hak dan nafkah kepada istri-istrinya. ${ }^{31}$ Islam sendiri tidak

Equality:International Jurnal of Child and Gender Studies, Volume. 1, No. 1, Maret 2015, 28. Lihat juga Siti Hikmah, "Fakta Poligami Sebagai Bentuk Kekerasa Terhadap Perempuan", Sawwa, Volume. 7, No. 2, April 2012, 6.

${ }^{27}$ Sayuti Thalib, Hukum Kekeluargaan Indonesia (Jakarta: Universitas Indonesia, 1986), 55.

${ }^{28}$ Reza Fitra Ardhian, Satrio Anugrah, Setyawan Bima, "Poligami dalam Hukum dan Hukum Positif Indonesia Serta Urgensi Pemberian Izin Poligami di Pengadilan Agama", Privat Law, Volume. III, No. 2, Juli-Desember 2015, 101.

${ }^{29}$ Abdul Jalil, "Wanita dalam Poligami (Studi Pemikiran Muhammad Syahrur", CENDIKIA: Jurnal Studi Keislaman, Volume. 2, No. 1, Juni 2016, 1.

${ }^{30}$ AzwarFajri, "Keadilan Berpoligami dalam Perspektif Psikologi”, Jurnal Substansi, Volume. 13, No. 2, Oktober 2011, 161.

${ }^{31}$ Muhammad Sayyid Tantawi, al-Tafsir al-Wasit li al-Qur'an al-Karim, (Kairo: Dar al-Sa'adah, 1983), jilid 3, 42 . 
melarang poligami, selama mereka (laki-laki) dapat adil kepada isteri-isterinya. Karena kemampuan adil merupakan salah satu syarat seorang laki-laki boleh berpoligami. ${ }^{32}$

Di kalangan ulama tradisional pun sebenarnya tidak mempersoalkan tentang boleh tidaknya melakukan poligami karena itu sudah dijelaskan oleh surah an-Nisā' [4]: 3. Mereka hanya berselisih mengenai jumlah perempuan yang boleh dinikahi oleh laki-laki dalam waktu yang bersamaan. ${ }^{33}$ Namun bagi ulama modern, walaupun tidak melarang praktik poligami, akan tetapi mereka memperberat syarat poligami. Bahkan seperti Muhammad Abduh dalam upayanya melakukan pembaharuan Islam. Ia mengatakan bahwa poligami yang semula menjadi salah satu solusi atas permasalahan sosial di masyarakat, ternyata dalam praktiknya justru banyak menimbulkan masalah dan sering disalah artikan. Misi poligami yang pada awalnya melindungi para janda serta anak-anak yatim dari ketidakadilan, ternyata banyak yang beralih pada upaya pemenuhan nafsu syahwat dan penguasaan kaum laki-laki atas perempuan. ${ }^{34}$

Sementara menurut Muhammad Sayyid Ṭantāwī, dispensasi yang diberikan oleh alQur'an tentang bolehnya poligami bukan tidak ber-alasan, sebab kalau ditinjau dari aspek kemanusiaan, laki-laki memiliki hasrat yang lebih tinggi dari wanita, sehingga perlu untuk disalurkan. Maka dari itu, untuk menghindari perbuatan zina, al-Qur'an memberikan dispensasi untuk berpoligami. ${ }^{35}$ Di sisi lain, perempuan mempunyai masa menstruasi dan hamil, sehingga tidak setiap saat bisa berhubungan intim dengan laki-laki, atau kondisi istri dalam keadaan mandul sedangkan

\footnotetext{
${ }^{32}$ Tofan Madiu, "Praktik Poligami dalam Perspektif Hukum Islam", Lex Privatum, Volume. II, No. 1, JanMaret 2014, 32.

${ }^{33}$ Abd. Moqsith, "Tasir atas Poligami dalam alQur'an”, Karsa, Volume. 23, No. 1, Juni 2015, 136.

${ }^{34}$ Agus Sunaryo, "Poligami di Indonesia (Sebuah Analisis Normatif-Sosiologis)", Yin Yang: Jurnal Studi Gender \& Anak, Volume. 5, No. 1, Jan-Juni 2010, th.

${ }^{35}$ Muhammad Sayyid Tāntāwī, Al-Tafsìr al-Wasìt Li al-Qur'ān al-Karìm, Vol. 3, 35.
}

suami ingin mempunyai keturunan. Dalam kondisi seperti inilah, poligami menjadi pilihan alternatif. ${ }^{36}$ Hal ini sebagaimana ditegaskan oleh Muhammad Sayyid Tāntāwī dalam kitab tafsirnya:

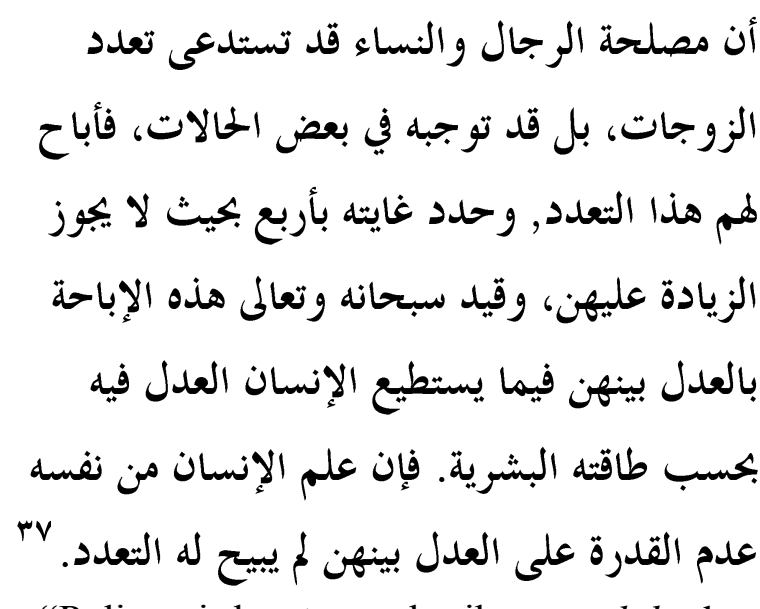

"Poligami dapat memberikan maslaha bagi laki-laki dan perempuan-bahkan poligami menjadi wajib dalam keadaan tertentu-Maka untuk itulah Allah membolehkan poligami dengan batasan empat orang istri dan tidak boleh lebih. Kebolehan poligami ini diikuti dengan syarat yaitu adil menurut kadar kemanusiaan. Namun, jika ia tahu bahwa tidak akan dapat berbuat adil, maka poligami tidak dibolehkan"

Dalam masalah poligami ini, Muhammad Sayyid Tāntāwī memberi batasan tentang jumlah istri yang boleh dinikahi oleh laki-laki dalam satu waktu, yaitu tidak boleh lebih dari empat orang. Ia juga mengkritik penafsiran lain yang membolehkan laki-laki menikahi perempuan lebih dari empat orang istri. Menurut Muhammad Sayyid Tāntāwī, penafsiran tersebut keliru di dalam memahami huruf " $w \bar{a} w u$ " pada kalimat "maśnā wa

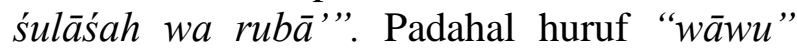
pada kelimat tersebut menurut Muhammad Sayyid Tāntāwī adalah "wāwu badal" yang berarti pengganti. Seakan-akan ayat tersebut berbunyi "ankihū śalāśan baddalan min maśnā, wa rubā' baddalan min śulāś" dan

\footnotetext{
${ }^{36}$ Muhammad Sayyid Tāntāwī, Al-Tafsīr al-Wasīt Li al-Qur'ān al-Karìm, Vol. 3, 42.

37 Muhammad Sayyid Tāntāwī, Al-Tafsīr al-Wasīt Li al-Qur'ān al-Karìm, Vol. 3, 42.
} 
bukan " $w \bar{a} w u$ 'atf" yang berarti penjumlahan. Sehingga dengan demikian, menikahi perempuan lebih dari empat orang dalam satu waktu, itu tidak dibolehkan. ${ }^{38}$

Walaupun pendapat Muhammad Sayyid Tāntāwī tentang poligami ini tidak jauh beda dengan mayoritas ulama tradisional dalam membolehkan praktik poligami, namun menurut Muhammad Sayyid Tāntāwī, masalah poligami ini bukanlah hal yang bisa dilakukan oleh semua orang. Sebab, poligami yang dibolehkan oleh al-Qur'an hanyalah merupakan dispensasi bagi kaum laki-laki yang merasa mampu untuk berbuat adil pada semua istrinya. Namun, bagi mereka (lakilaki) yang merasa tidak akan dapat berbuat adil kepada semua istrinya, maka sebaiknya dicukupkan satu saja. Dengan begitu ia akan terjaga dari berbuat dzalim dan aniaya. AlQur'an memang tidak melarang poligami, namun bukan berarti menganjurkannya. ${ }^{39}$ Dan poligami bukanlah solusi yang sangat menyenangkan sepanjang memperhatikan alQu'an. ${ }^{40}$

Tidak hanya itu, Muhammad Sayyid Tāntāwī juga mengkritik penafsiran yang mengharamkan poligami. Menurut Muhammad Sayyid Tāntāwī, mereka yang tidak mengharamkan poligami karena tidak dapat memahami ajaran Islam dengan benar. Sehingga ayat " $f \bar{a}$ in hiftum an lā ta'dilu fawāhidah" dan ayat "wa lan tastatī'ū an ta'dilü" dipahami sebagai ayat yang melarang poligami secara syara'. Karena adil menurut mereka (yang mengharamkan poligami) meliputi perasaan cinta dan kencenderungannya. Oleh karena itu, Muhammad Sayyid Tāntāwī mengkritik penafsiran tersebut karena adil yang dimaksud oleh mereka (yang mengharamkan poligami)

\footnotetext{
${ }^{38}$ Muhammad Sayyid Tāntāwī, Al-Tafsīr al-Wasìt Li al-Qur'ān al-Karìm, Vol. 3, 40.

${ }^{39}$ Sofwan Ahadi, "Pembagian Harta Bersama dalam Perkawinan Poligami”, Isti'dal: Jurnal Studi Hukum Islam, Volume. 1, No. 1, Januari-Juni 2014, 91.

${ }^{40}$ Asghar Ali Engineer, Pembebasan Perempuan, “terj." Agus Nuryatno (Yogyakarta: LkiS, 2003), 112.
}

diluar batas kemampuan manusia. ${ }^{41}$ Namun, bukan berarti Muhammad Sayyid Tāntāwī menganjurkan untuk melakukan poligami, karena poligami yang dilegalkan oleh Islam memiliki syarat yang berat, dan batasan jumlah yang jelas. ${ }^{42}$

Terkait kata adil, di kalangan para ulama sendiri berbeda pendapat, karena sifat adil itu sangat subyektif sifatnya, ${ }^{43} \mathrm{di}$ antaranya: 1) AlMaraghi memaknai adil dengan menyampaikan hak kepada pemiliknya secara efektif. 2) Raghib al-Asfahani menyebutkan bahwa lafadz tersebut bermakna memberi pembagian yang sama. 3) Quraish shihab mengemukakan bahwa kata adil pada awalnya diartikan dengan sama atau persamaan, itulah yang menjadikan pelakunya tidak memihak atau berpihak pada yang benar. ${ }^{44}$ ). Sementara menurut Khazin Nasuha, yang dimaksud dengan keadilan dalam poligami adalah adil dalam materi, dalam membagi waktu, adil membagi nafkah yang berkaitan dengan nafkah sandang, pangan, papan, dan adil dalam memperlakukan kebutuhan batiniah istriistrinya. Dalam hal keadilan batiniah memang tidak dituntut dalam syariah Islam karena masalahnya berada di luar kemampuan manusia. $^{45}$

Sementara Menurut Muhammad Sayyid Tāntāwī, yang dimaksud adil adalah adil dalam memberikan nafkah dan hak-hak istri menurut kemampuannya sebagai manusia. ${ }^{46}$ Adapun mengenai perasaan cinta

${ }^{41}$ Muhammad Sayyid Tāntāwī, Al-Tafsīr al-Wasīt Li al-Qur'ān al-Karīm, Vol. 3, 442.

${ }_{42}$ Muhammad Sayyid Tāntāwī, Al-Tafsīr al-Wasīt Li al-Qur'ān al-Karìm, Vol. 3, 40.

${ }^{43}$ Ria Renita Abbas, "Institusi Keluarga dan Poligami (Studi Kasus Keluarga Poligami yang Berpoligini di Kota Makasar)", Socious, Volume. XV, Januari-April 2014, 79.

${ }^{44}$ Haris Hidayatullah, "Adil dalam Poligami Perspektif Ibn Hazm”, Religi: Jurnal Studi Islam, Volume. 6, No. 2, Oktober 2015, 210.

${ }^{45}$ Boedi Abdullah, Beni Ahmad Saebani, Perkawinan Perceraian Keluarga Muslim (Bandung: Cv Pustaka Setia, 2013), 32.

${ }^{46}$ Muhammad Sayyid Tāntāwī, Al-Tafsīr al-Wasīt Li al-Qur'ān al-Karìm, Vol. 3, 
dan kecenderungannya, menurut Muhammad Sayyid Tāntāwī bukanlah termasuk syarat poligami, karena manusia tidak akan mampu membaginya secara adil di antara para istriistrinya dan itu diluar kemampuannya sebagai manusia. Oleh karena itu, surah an-nisā' [4]: 129 yang dijadikan dalil oleh sebagian ulama untuk mengharamkan poligami menurut Muhammad Sayyid Tāntāwī dinilai kurang tepat, karena adil yang dijadikan syarat oleh Allah dalam bolehnya praktik poligami tersebut diukur dengan kemampuan manusia itu sendiri, seperti: adil dalam memberikan nafkah, pakaian, rumah dan hal lain yang sekiranya itu masih dapat diusahakan. ${ }^{47}$

\section{Poligami Disorot dari Sejarahnya}

Jika dilihat dari kronologi turunnya surah an-Nisā' [4]: 3 ini, dapat dikatakan bahwa poligami yang dibicarakan oleh ayat di atas adalah mengenai persoalan anak yatim perempuan yang dinikahi oleh pengasuhnya. Dan memang pada waktu itu, sudah merupakan kebiasaan laki-laki Hijaz menikahi perempuan-perempuan yatim demi untuk menguasai harta mereka. Setelah menikah, perempuan yatim tersebut tidak mendapatkan maskawin layaknya perempuan-perempuan lain, padahal maskawin merupakan hak istri yang harus diberikan oleh suami sebagai syarat sahnya sebuah pernikahan. Selain itu, perempuan-perempuan yatim ini mendapatkan perlakuan tidak baik dari suami mereka, dan juga tidak mendapatkan hak sebagai seorang istri. 48

Dalam hadits yang diriwayatkan oleh Imam Bukhārī, Muslim, Abū Dāud dan Nasā'̄̄ dari 'Urwah bin Zubair, sebagaimana dinukil oleh Muhammad Sayyid Tāntāwī dalam kitab tafsirnya bahwa 'Urwah bin Zubair bertanya

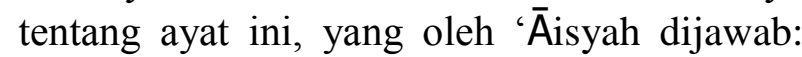
Wahai anak saudariku, ayat ini diturunkan berkaitan dengan perempuan yatim yang dipelihara oleh walinya, harta dan kecantikan perempuan yatim itu kemudian menarik hati

\footnotetext{
${ }^{47}$ Muhammad Sayyid Tāntāwī, Al-Tafsìr al-Wasìt Li al-Qur'ān al-Karīm, Vol. 3, 442.

${ }_{48}$ Muhammad Sayyid Tāntāwī, Al-Tafsīr al-Wasìt Li al-Qur'ān al-Karìm, Vol. 3, 33.
}

wali tersebut dan ingin menikahinya. Tetapi, setelah menikah ternyata si wali itu tidak berlaku adil, dia tidak mau memberi maskawin sebagaimana yang diberikan suami kepada istrinya. 49

Melihat kondisi yang seperti itu, menurut Muhammad Sayyid Tāntāwī surah an-Nisā' [4]: 3 ini diturunkan tidak lain adalah sebagai teguran bagi laki-laki Hijaz yang suka menikahi perempuan yatim yang diasuhnya demi untuk menguasai harta mereka. Untuk itu, Muhammad Sayyid Tāntāwī menegaskan bahwa jika pernikahan itu didorong oleh keinginan untuk menguasai harta mereka (yatim perempuan yang sedang diasuh) saja, sebaiknya keinginan tersebut tidak diteruskan. Sebagai solusinya, al-Qur'an membolehkan bagi laki-laki yang demikian itu untuk menikahi perempuan lain (selain yatim-yatim perempuan yang diasuh) dengan batasan tidak lebih dari empat orang istri. ${ }^{50}$

Tradisi poligami ini sebenarnya sudah ada sebelum Islam datang. Pada masa jahiliyah, tidak ada pembatasan tentang jumlah istri yang dapat dimiliki oleh seorang laki-laki. Para pemuka dan pemimpin mempunyai banyak istri untuk menjalin hubungan dengan keluarga lainnya. Praktik pembujukan keluarga lain dan aliansi politik melalui perkawinan ini diperaktikkan dalam masyarakat feodal lainnya dalam skala yang sangat besar. $^{51}$ Sebab, status sosial yang berlaku waktu itu adalah menempatkan peran dominan kekuasan pada kelompok sosial dengan berdasarkan pada kepemilikan sejumlah budak. ${ }^{52}$ Sementara dalam Islam, praktik poligami ini dibolehkan hanya dalam keadaan tertentu saja (darurat), jika hal itu berkaitan dengan kepentingan dan maslaha manusia itu sendiri. Untuk itulah, Islam membolehkan poligami ini disertai dengan

\footnotetext{
${ }^{49}$ Muhammad Sayyid Tāntāwī, Al-Tafsīr al-Wasìt Li al-Qur'ān al-Karīm, Vol. 3, 33.

${ }^{50}$ Muhammad Sayyid Tāntāwī, Al-Tafsìr al-Wasìt Li al-Qur'ān al-Karìm, Vol. 3, 34.

${ }^{51}$ Nurjannah Ismail, Perempuan dalam Pasungan, 35.

${ }^{52}$ Zaitunah Subhan, Al-Qur'an dan Perempuan (Jakarta: PT Fajar Interpratama Mandiri, 2015), 285.
} 
syarat yang berat dan batasan jumlah yang jelas. $^{53}$

\section{Analisis Muhammad Sayyid Tāntāwī Terhadap poligami}

Usaha Muhammad Sayyid Tāntāwī untuk bersikap adil terkait masalah poligami menurut penulis dapat dilihat dari pendapatnya tentang ketentuan dan syarat poligami yang harus dipenuhi oleh seorang laki-laki. Bahwa laki-laki yang merasa dirinya tidak akan dapat berbuat adil terhadap istri-istrinya, maka tidak dibolehkan melakukan poligami, karena kalau dipaksakan ia hanya akan berbuat aniaya dan lalim terhadap mereka.

Walaupun penafsiran Muhammad Sayyid Tāntāwi terkait masalah poligami ini tidak jauh beda dengan pemikiran ulama-ulama tradisional. Di mana ia juga membolehkan adanya praktik poligami. Namun, menurut penulis penafsiran yang dilakukan oleh Muhammad Sayyid Tāntāwī lebih menekankan terhadap maslaha perempuan dengan memperberat syarat bolehnya poligami serta memberikan batasan yang jelas tentang jumlah istri yang boleh dinikahi oleh laki-laki dalam satu waktu.

Penulis melihat poligami yang dikehendaki oleh Muhammad Sayyid Tāntāwī berbeda dengan poligami yang terjadi di lapangan. Kebanyakan dari mereka memilih istri kedua, ketiga dan keempat bukan karena ingin melindungi dan mengayomi, tapi lebih kepada hasrat seksual untuk memiliki dengan melihat paras, bentuk tubuh dan kekayaan yang dimilikinya. Seperti kasus pernikahan beda umur yang sempat menggemparkan Indonesia pada tahun 2008 lalu. Seorang pria berinisial (SP) berumur 50-an tahun asal semarang menikahi perempuan berumur 12 tahun berinisial (LU) sebagai istri kedua.

Merujuk pada pandangannya Muhammad Sayyid Tāntāwī terkait masalah poligami ini, jika ia ingin mengambil istri kedua, ketiga dan keempat seharusnya menikahi perempuan miskin yang sedang menanggung beban hidup anak-anaknya dan sedang dalam kesulitan,

\footnotetext{
${ }^{53}$ Muhammad Sayyid Tāntāwī, Al-Tafsīr al-Wasīt Li al-Qur'ān al-Karìm, Vol. 3, 42.
}

atau perempuan tua yang sedang butuh pengayoman karena ditinggal oleh suaminya, seperti yang dicontohkan oleh Rasulullah Saw.

Dalam tafsirnya, Muhammad Sayyid Tāntāwī berusaha untuk bersikap semoderat mungkin terkait masalah poligami ini dengan menunjukkan bahwa poligami merupakan dispensasi yang diberikan oleh al-Qur'an kepada laki-laki, karena keadaan darurat. Seperti istri tidak dapat memberikan keturunan disebabkan suatu penyakit atau istri dalam keadaan sakit dan tidak dapat menunaikan kewajibannya sebagai seorang istri.

Menurut penulis, alasan hasrat ini masih berpihak kepada laki-laki, sehingga memicu terjadinya subordinasi terhadap istri pertama. Sebab, Muhammad Sayyid Tāntāwī tidak membahas bagaimana jika istri pertama tidak setuju, apakah poligami masih dilegalkan. Di sisi lain, terdapat adanya diskriminasi gender yang terdapat pada alasan dibolehkannya poligami yaitu mandul. Padahal penyakit mandul tidak hanya dimiliki oleh perempuan saja. Untuk alasan-alasan tersebut, penulis sepakat dengan pendapatnya Amina Wadud yang mengatakan bahwa poligami bukanlah solusi, yang terpenting adalah pengendalian diri sehingga mampu meredam hasrat tersebut.

\section{SIMPULAN}

Menurut Muhammad Sayyid Tāntāwī masalah poligami ini bukanlah hal yang bisa dilakukan oleh semua orang. Sebab, poligami yang dibolehkan oleh al-Qur'an hanyalah merupakan dispensasi bagi kaum laki-laki yang merasa mampu untuk berbuat adil pada semua istrinya. Namun, bagi mereka (lakilaki) yang merasa tidak akan dapat berbuata adil di antara istri-istrinya, maka sebaiknya dicukupkan satu saja. Dengan begitu ia akan terjaga dari berbuat dzalim dan aniaya.

Namun dalam saat-saat tertentu, poligami menjadi urgen untuk dipraktikan. Sebab kalau ditinjau dari aspek kemanusiaan, laki-laki memiliki hasrat yang lebih tinggi dari wanita, sehingga perlu untuk disalurkan. Maka dari itu, untuk menghindari perbuatan zina, al- 
Qur'an melegalkan poligami dengan batasan tidak boleh lebih dari empat orang. Pada aspek inilah pendapat Tantawi ini masih terlihat bias ender.

\section{DAFTAR PUSTAKA}

Abbas, Ria Renita. "Institusi Keluarga dan Poligami (Studi Kasus Keluarga Poligami yang Berpoligini di Kota Makasar)", Socious, Volume. XV, Januari-April 2014.

Abdullah, Boedi. dan Saebani, Beni Ahmad. Perkawinan Perceraian Keluarga Muslim. Bandung: Cv Pustaka Setia, 2013.

Ahadi, Sofwan. "Pembagian Harta Bersama dalam Perkawinan Poligami", Isti'dal: Jurnal Studi Hukum Islam, Volume. 1, No. 1, Januari-Juni 2014.

Ali Engineer, Asghar. Pembebasan Perempuan, "terj." Agus Nuryatno. Yogyakarta: LkiS, 2003.

Amin Suma, Muhammad. Ulumul Qur'an. Jakarta: PT RajaGrafindo Persada, 2013.

Ardhian, Reza Fitra. Anugrah, Satrio. Bima, Setyawan. "Poligami dalam Hukum dan Hukum Positif Indonesia Serta Urgensi Pemberian Izin Poligami di Pengadilan Agama", Privat Law, Volume. III, No. 2, Juli-Desember 2015.

Arifah, Anis Nur. Sholehah, Reniyadus. Hardiyanto, Triwahju. "Poligami Kyai: Praktek Poligami Kyai di Kota Jember dalam Pandangan KHI dan Gender", dalam jurnal Yudisia, Volume. 7, No. 1, Juni 2016.

Baidan, Nashruddin. Wawasan Baru Ilmu Tafsir, cet. ke-2. Yogyakarta: Pustaka Pelajar, 2011. Islah Gusmian, Khasanah Tafsri Indonesia. Yogyakarta: LkiS, 2013.

Dakhoir, Ahmad. "Poligami dan Power Ekonomi", Jurnal al-Qardh, Volume. 1, No. 1, Juli 2016.

Darmawijaya, Edi. "Poligami dalam Hukum Islam dan Hukum Positif", Gender Equality:International Jurnal of Child and Gender Studies, Volume. 1, No. 1, Maret 2015.

Dzuhayatin, Siti Ruhaini. Rezim Gender Muhammadiyah: Kontestasi Gender,
Identitas, dan Eksistensi. Yogyakarta: Suka Press UIN \& Pustaka Pelajar, 2015.

Faisol, Ach. "Perubahan Sosial dalam Praktik Poligami di Indonesia Perspektif Analisis Teori Faktor Independen Neil J. Smelser", Jurnal Ilmiah Vicratina, Volume. 10, No. 2, November 2016.

Fajri, Azwar. "Keadilan Berpoligami dalam Perspektif Psikologi", Jurnal Substansi, Volume. 13, No. 2, Oktober 2011.

Habibi, Nuril. "Persamaan Hak Antara Lakilaki dan Perempuan Menurut Muhammad Sayyid. Tāntāwī”, dalam jurnal Al-'Adalah, Vol. 1, No. 2, Januari 2018.

Hadiyanto, Andi. "Wacana Poligami dalam penafsiran al-Qur'an", Jurnal Studi alQur'an, Volume. IV, No. 1, 2008.

Hidayatullah, Haris. "Adil dalam Poligami Perspektif Ibn Hazm”, Religi: Jurnal Studi Islam, Volume. 6, No. 2, Oktober 2015.

Hikmah, Siti. "Fakta Poligami Sebagai Bentuk Kekerasa Terhadap Perempuan", Sawwa, Volume. 7, No. 2, April 2012.

Intan, Salmah. "Kedudukan Perempuan dalam Domestik dan Publik Perspektif Gender" dalam jurnal Politik Profetik, Vol. 3, No. 1, 2014.Inayah Rohmaniyah, Konstruksi Patriarki dalam Tafsir Agama: Sebuah Jalan Panjang. Yogyakarta: Diandra Pustaka Indonesia, 2014.

Iyāzī, Sayyid Muḥammad 'Alī. al-Mufassirūn Hayātuhum wa Manhājuhum, Jilid. III. Teheran: Wizārat Śaqāfah wa al-Irsyād alIslāmi, $1386 \mathrm{H}$.

Izzan, Ahmad. Metodologi Ilmu Tafsir. Bandung: Tafakur, 2011.

Jalil, Abdul. "Wanita dalam Poligami: Studi Pemikiran Muhammad Syahrur", dalam jurnal CENDIKIA: Jurnal Studi Keislaman, Volume. 2, No. 1, Juni 2016.

Karim, Khalil Abdul. Syari'ah Sejarah Perkelahian Makna. Yogyakarta: LkiS, 2003.

Ma'mur, Jamal. Rezim Gender di NU. Yogyakarta: Pustaka Pelajar, 2015.

Madiu, Tofan. "Praktik Poligami dalam Perspektif Hukum Islam", Lex Privatum, Volume. II, No. 1, Jan-Maret 2014.

Moqsith, Abd. "Tasir atas Poligami dalam al- 
Qur'an”, Karsa, Volume. 23, No. 1, Juni 2015

Muhibbuthabry, "Poligami dan Sankinya Menurut Perundang-undangan NegaraNegara Modern", Ahkam, Volume. XVI, No, 1, Januari 2016.

Mukhtar, Naqiyah. Ulumul Qur'an. Purwokerto: STAIN Press, 2013.

Nugroho, Riant. Gender dan Strategi Pengarus-Utamaannya di Indonesia. Yogyakata: Pustaka Pelajar, 2011.

Purwaningsih, Sri. Kiai \& Keadilan Jender. Semarang: Walisongo Pers, 2009.

Ridho, Mohammad. Islam, Tafsir dan Dinamika Sosial: Ikhtiar Memaknai Ajaran Islam. Yogyakarta: Teras, 2010.

Rohmat, "Poligami dalam al-Qur'an", dalam jurnal Tribakti, Volume. 14, No. 2, Juli 2005.

Sayyid asy-Syuri, Madji bin Manshur bin. Mahkota Pengantin-Bingkisan Istimewa untuk Istri, "terj”. Ahmad Syaikhu. Jakarta: Pustaka at-Tazkia, 2017.

Sofyan, Aa. "Analisis Pemkikiran Musdah Mulia Terhadap Keharaman Poligami", dalam jurnal Bil Dalil (Jurnal Hukum Islam Keluarga), Volume. 1, No. 2, JuliDesember 2016.

Sunaryo, Agus. "Poligami di Indonesia;
Sebuah Analisis Normatif-Sosiologis", Yin Yang: Jurnal Studi Gender \& Anak, Volume. 5, No. 1, Jan-Juni 2010.

Suratman, Junizar. "Pendekatan Penafsiran alQur'an yang Didasarkan pada Instrumen Riwayat, Nalar, dan Isyarat Batin", dalam jurnal Intizar, Vol. 20, No. 1, 2014.

Tamu, Yowan. "Poligami dalam Teori Hermeneutika Muhammad Shahrur", Mutawatir: Jurnal Keilmuan Tafsir Hadis. Volume. 2, No. 1, Juni 2011.

Tantawi, Muhammad Sayyid. al-Tafsir alWasit li al-Qur'an al-Karim. Kairo: Dar alSa'adah, 1983, jilid 3.

Thalib, Sayuti. Hukum Kekeluargaan Indonesia. Jakarta: Universitas Indonesia, 1986.

Tihami, dan Sahrani, Sohari. Fikih Munakahat-Kajian Fikih Nikah Lengkap. Jakarta: Rajawali Pers, 2013.

Usman, Ilmu Tafsir. Yogyakarta: Teras, 2009.

Zamroni, Muhammad. "Perempuan dalam Kajian Komunikasi Politik dan Gender", dalam jurnal Dakwah, Vol. XIV, No. 1, Jan-Des 2013.

technical 